\title{
OPTIMIZING DELIVERY ROUTE BY APPLYING MILKRUN METHOD
}

\author{
Putri Setiani $^{1}$, Hanifah Fiddieny ${ }^{2}$, Edhie Budi Setiawan ${ }^{3}$, Diah Etika \\ Cahyanti $^{4}$ \\ 1. STMT Trisakti, 2. STMT Trisakti, 3.STMT Trisakti, 4. STMT Trisakti \\ $\triangle$ corresponding author:Putrisetiani30@gmail.com
}

\begin{abstract}
Efficiency of the optimal vehicle route to generate effective delivery is an important issue in the logistics world. The common methods usually practiced in delivery systems are direct shipment, indirect shipment and milk run method. The objective of this research is to analyze the optimization of delivery route by comparing direct shipment method to milk run method to obtain effective delivery. This research involved 8 suppliers and 1 delivery route from the total population of 18 suppliers at PT. Toyota Motor Manfacturing Indonesia and 4 delivery routes in Cikarang area. Data were analyzed by using Vehicle Routing Problem and saving matrix method. The result shows that the optimal delivery route can minimize the distance and vehicle leadtime, therefore, the total cost spent in the milkrun delivery process is cheaper than by applying direct shipment method. It can be concluded that regular parts shipment process by using milk run method is more effective than by using direct shipment method.
\end{abstract}

Keywords: Optimal Route, Milk Run, Direct Shipment

\section{Introduction}

Delivery system plays an important part in logistics. Delivery of goods in a country is dependent to public infrastructure of that country. Then the delivery process needs a high efficiency in logistics activities, including the level of security quality, safety and service (S, 2016). The common delivery system applied in most companies in distributing goods is the direct shipment method. According Li, Wu, Lai, \& Liu, (2008) direct shipment method is a delivery method that is practiced in a company in which the supplier provides a vehicle used per period of time to one customer or a retailer. Another definition explained by Sadjadi, Jafari, \& Amini (2009), direct shipment is a direct delivery from a supplier to its customer. In other words, direct shipment is a delivery system done directly from a supplier to a customer by using a vehicle to serve one specific customer. 
Table 1 Total Cost of Direct Shipment

\begin{tabular}{|l|l|l|l|}
\hline $\begin{array}{l}\text { DIRECT SHIPMENT } \\
\text { ROUTE }\end{array}$ & $\begin{array}{l}\text { Distance/10 } \\
\text { days }\end{array}$ & $\begin{array}{l}\text { Shipment } \\
\text { Volume }\end{array}$ & Total Cost/10 Days \\
\hline A-DC-A & 460,00 & 1,12 & Rp 10.060.000,00 \\
\hline B-DC-B & 494,80 & 0,33 & Rp 10.442.800,00 \\
\hline E-DC-E & 485,20 & 1,73 & Rp 10.337.200,00 \\
\hline F-DC-F & 467,20 & 12,2 & Rp 14.139.200,00 \\
\hline G-DC-G & 484,80 & 0,46 & Rp 10.332.800,00 \\
\hline H-DC-H & 475,20 & 4,24 & Rp 10.227.200,00 \\
\hline J-DC-J & 482,80 & 5,67 & Rp 10.310.800,00 \\
\hline L-DC-L & 461,60 & 10,91 & Rp 14.077.600,00 \\
\hline TOTAL & 3811,60 & 36,66 & $R p 89.927 .600,00$ \\
\hline
\end{tabular}

The increase number of production has obliged PT. Toyota Motor

Manufacturing Indonesia to reconsider about the route and the delivery cost. A study done byBell \& McMullen (2004), confirmed that efficiency of the vehicle route is an important issue in logistics business, as the optimal delivery route will generate effective delivery. This is also supported by Sari (2015) efficiency and effectiveness in the delivery process needs to know the best route. One way to enhance efficiency in delivering goods is by applying the Milk run method. Milk run method is a delivery system in which vehicles are rotating based on a schedule defined before, stopping at every department to collect products that have been ordered (Kovács, 2011).

Derived from the condition above, this research is conducted to find an optimal route for milk run delivery method in achieving the effective regular parts shipments. How effective is the milk run delivery method compared to direct shipment method?

The research is done to find out the optimal delivery by practicing Milk Run system to achieve the effective and efficient delivery system. Nemoto \& Rothengatter (2012) stated that the Milk run delivery system deals with suppliers of a company or several suppliers from different cooperating companies and the delivery is done by the third party logistic (3PL) or fourth party logistic (4PL). Whereas in the process of material handling, milk run performs as the waste and cost reduction under consideration that this system does the delivery by using one mobile vehicle periodically in a certain route 
so that it will reduce fuel consumption (Kilic \& Durmusoglu, 2012). Furthermore, the result of the milk run system is reducing transportation cost, route and fuel consumption (Kovács, 2011). Based on the previous researches, it can be concluded that milk run delivery system is a system that uses one vehicle rotating and visiting every customers and suppliers in one route based on order. It is done to increase efficiency of the vehicle (truck), to reduce delivery cost and to achieve effective delivery.

According to Sadjadi et al., (2009) direct shipment method is where the consignments are directly delivered to the manufacturers from the suppliers, and the company is responsible for storing the general inventory. This logistic pattern is traditionally used for supplying all parts. In other words the shipment is done directly from supplier to customers, the advantage of applying this method is the goods can be delivered faster without having to wait for another customers. However it takes more vehicles and more cost to spend.

A research done by Iqbal (2013) suggested that optimization is a way in finding optimal solution, at the same time, overcoming resource constraints and minimizing cost, maximizing profits and improving process efficiency. Witlox (2007) stated, delivery route planning involves ordering center in a certain area, so that it can optimize traveling time, and transport operation between customer and supplier. A company that is able to cut down the delivery route and lessen the number ofvehicles used would be able to increase its added value.In accordance with a research done by Endarwati, Mahmudy, \& Ratnawati (2014), to shorten delivery process time, companies should choose the most optimal routes. By applying the milk run method, it is expected to reduce the costs during delivery process, reduce the use of warehouse space, and improve the supply chain performance or logistic as a consequence of the effective transport process (Sadjadi et al., 2009). 


\section{Method}

In this research, researchers used delivery volume data and delivery route data from several suppliers to PT. TMMIN. Data were gathered by doing observation in logistic division of PT. TMMIN in September to November 2017. Researchers took samples from 8 suppliers and 1 delivery route from the total population of 18 suppliers and 4 delivery route in Cikarang area. In analyzing data, researchers employed the Vehicle Routing Problem (VRP) method that is applied to decide the optimal route which will be taken by the vehicles, focusing on one depot or more to serve several customers. There are some conditions in the application of vehicle routing problem, for instance, each route should not exceed vehicle capacity, and the total length of each route should not be greater than the set limit. The general purpose of VRP are to minimize distance and costs of the vehicles, minimize the number of vehicles used to serve all costumers, balance time per route, and so forth (Toth \& Vigo 2002). A research done by Poot, Kant, \& Wagelmans (2002) explained that saving method is a method to minimize distance, time and costs by considering the constraints. Coordinate points of the original distance to the destination will be measured, and the millage of all vehicles will be minimized afterward.

This research also employed steps in saving matrix method initiated by Pujawan\&Mahendrawathi (2010). The first step is determining the coordinates of each supplier locations to recognize distance between locations. The second step is calculating distance saving by using saving matrix. Integrating two or more suppliers into one delivery route. The third step is allocating suppliers into vehicle or delivery route. Truck specification from 3PL party which will transport the regular parts from every supplier in one route is wing box trucks, the specifications are as followed:

Table 2 Transport Capacity Wing Box Truck

\begin{tabular}{|l|l|l|}
\hline Max Wing Box Truck Capacity & $7.5 \times 2.4 \times 2.4$ & $43.2 \mathrm{~m} 3$ \\
\hline Buffer for Loading Operation & $0.2 \times 7.5 \times 2.4$ & $3.6 \mathrm{~m} 3$ \\
\hline Transport Capacity & & $39.6 \mathrm{~m} 3$ \\
\hline
\end{tabular}


The fourth step is determining truck visit order to each supplier by sweep method. Determining the order of trucks visit started from DC then found the nearest supplier from DC, proceeded to the next suppliers clockwise or counter clock-wise, additional suppliers in each visit would be accumulated based on its distance, hence the length of the distance that must be taken by truck will be obtained. Another explanation was given by Supriyadi, Mawardi, \& Nalhadi (2017) saving method with sweep method is used to decide vehicle schedulein optimal route. Saving matrix is also applied to determine products distribution route to target market by deciding the distribution route that should be taken and the number of vehicles which is suitable with the capacity to attain the shortest route and minimum costs. The visit order would then be determined by sweep method. Sweep is a part of saving matrix method used to decide the order of visit routes, done by drawing a straight line from DC to the nearest destination then proceed to another destination clock-wise or counter clock-wise. Hourilson, Souza, \& Fluminense (2011) also explained that the sweep method is a method done as the first step of the movement in determining order of visit to several suppliers. The result of the optimizing milk run method from the four steps above will then be compared based on costs, distances, and leadtime to the one which is done in direct shipment method.

\section{Discussion and Result}

\section{A. Route Analysis}

The steps in determining optimal route by saving matrix derived from Pujawan\&Mahendrawathi (2010) are:

1. Determining the DC coordinate with suppliers' location and coordinates among suppliers.

Table 3 Coordinates of suppliers location and the amount of delivery volume.

\begin{tabular}{|c|c|c|c|c|c|c|}
\hline No & $\begin{array}{c}\text { Suppliers' } \\
\text { code }\end{array}$ & Suppliers & Location & \multicolumn{2}{|c|}{$\begin{array}{c}\text { Delivery } \\
\text { (Cikarang) }\end{array}$} & \multicolumn{2}{|c|}{ Colume $\left(\mathrm{m}^{3}\right)$} & $\mathrm{X}$ & $\mathrm{Y}$ \\
\cline { 5 - 7 } & $\mathrm{A}$ & $\begin{array}{c}\text { Sari Takagi } \\
\text { ElokProduk }\end{array}$ & Jababeka & 12,2 & 9,9 & $-6,2$ \\
\hline
\end{tabular}


Table 3, Cont.

Coordinates of suppliers location and the amount of delivery volume.

\begin{tabular}{|c|c|c|c|c|c|c|}
\hline 2 & B & $\begin{array}{c}\text { Takagi Sari } \\
\text { Multi Utama }\end{array}$ & $\begin{array}{c}\text { Delta } \\
\text { Silicon }\end{array}$ & 0,46 & 10,1 & $-6,7$ \\
\hline 3 & E & Otics Indonesia & EJIP & 10,91 & 8,85 & $-7,4$ \\
\hline 4 & F & $\begin{array}{c}\text { Ingress Malindo } \\
\text { Ventures }\end{array}$ & Jababeka 2 & 1,73 & 10,4 & $-6,25$ \\
\hline 5 & G & $\begin{array}{c}\text { Kojima Auto } \\
\text { Technology }\end{array}$ & Mall Lippo & 4,24 & 9,45 & $-7,2$ \\
\hline 6 & H & MTAT Indonesia & Jababeka 1 & 1,12 & 10,15 & $-5,4$ \\
\hline 7 & J & Sanoh Indonesia & Hyundai & 5,67 & 9,25 & $-7,75$ \\
\hline 8 & L & $\begin{array}{c}\text { Citra } \\
\text { NugerahKarya }\end{array}$ & Hyundai & 0,33 & 11,2 & $-5,25$ \\
\hline
\end{tabular}

As seen in table 1.3 the coordinates of each location, in this research is the distance in points $(\mathrm{X}, \mathrm{Y})$ describes the actual distance that should be taken by the vehicle and the length of time taken by the vehicle. The identified coordinates are put in saving matrix table.

Table 4 Distance between suppliers and Distance from DC to each suppliers

\begin{tabular}{|l|l|l|l|l|l|l|l|l|l|l|l|l|}
\hline & DC & A & B & C & D & E & F & G & H & I & J & K \\
\hline A & 11,7 & 0,0 & & & & & & & & & & \\
\hline B & 12,1 & 0,5 & 0,0 & & & & & & & & & \\
\hline C & 11,1 & 1,3 & 1,4 & 0,0 & & & & & & & & \\
\hline D & 11,2 & 1,6 & 1,6 & 0,3 & 0,0 & & & & & & & \\
\hline E & 11,5 & 1,6 & 1,4 & 0,6 & 0,4 & 0,0 & & & & & & \\
\hline F & 12,1 & 0,5 & 0,5 & 1,8 & 2,0 & 1,9 & 0,0 & & & & & \\
\hline G & 11,9 & 1,1 & 0,8 & 0,8 & 0,9 & 0,6 & 1,3 & 0,0 & & & & \\
\hline H & 11,5 & 0,8 & 1,3 & 2,0 & 2,3 & 2,4 & 0,9 & 1,9 & 0,0 & & & \\
\hline I & 11,0 & 0,8 & 1,3 & 1,5 & 1,8 & 2,0 & 1,2 & 1,7 & 0,7 & 0,0 & & \\
\hline J & 12,1 & 1,7 & 1,4 & 1,1 & 0,9 & 0,5 & 1,9 & 0,6 & 2,5 & 2,3 & 0,0 & \\
\hline K & 11,4 & 0,9 & 0,9 & 0,5 & 0,7 & 0,8 & 1,3 & 0,6 & 1,6 & 1,2 & 1,1 & 0,0 \\
\hline L & 12,4 & 1,6 & 1,8 & 2,9 & 3,2 & 3,2 & 1,3 & 2,6 & 1,1 & 1,7 & 3,2 & 2,5 \\
\hline
\end{tabular}


2. Calculating the saving distance to find the route combination.

Table 5 Saving distance among suppliers points

\begin{tabular}{|l|l|l|l|l|l|l|l|l|l|l|l|l|}
\hline & DC & A & B & C & D & E & F & G & H & I & J & K \\
\hline A & 11,7 & 0,0 & & & & & & & & & & \\
\hline B & 12,1 & 23,3 & 0,0 & & & & & & & & & \\
\hline C & 11,1 & 21,4 & 21,8 & 0,0 & & & & & & & & \\
\hline D & 11,2 & 21,3 & 21,7 & 21,9 & 0,0 & & & & & & & \\
\hline E & 11,5 & 21,6 & 22,2 & 22,0 & 22,3 & 0,0 & & & & & & \\
\hline F & 12,1 & $\mathbf{2 3 , 3}$ & $\mathbf{2 3 , 7}$ & 21,4 & 21,3 & 21,7 & 0,0 & & & & & \\
\hline G & 11,9 & 22,5 & 23,2 & 22,1 & 22,2 & 22,8 & 22,7 & 0,0 & & & & \\
\hline H & 11,5 & 22,3 & 22,3 & 20,5 & 20,4 & 20,7 & 22,7 & 21,5 & 0,0 & & & \\
\hline I & 11,0 & 21,9 & 21,8 & 20,5 & 20,3 & 20,5 & 22,0 & 21,2 & 21,8 & 0,0 & & \\
\hline J & 12,1 & 22,1 & 22,8 & 22,0 & 22,3 & $\mathbf{2 3 , 1}$ & 22,3 & $\mathbf{2 3 , 4}$ & 21,1 & 20,8 & 0,0 & \\
\hline K & 11,4 & 22,2 & 22,6 & 21,9 & 21,8 & 22,1 & 22,2 & 22,7 & 21,3 & 21,1 & 22,4 & 0,0 \\
\hline L & 12,4 & 22,4 & 22,7 & 20,5 & 20,3 & 20,7 & $\mathbf{2 3 , 2}$ & 21,6 & $\mathbf{2 2 , 8}$ & 21,7 & 21,3 & 21,3 \\
\hline
\end{tabular}

The integration is started from the biggest savings values in order to maximize savings. Two or more suppliers are integrated in one route. Table 1.5 shows that the biggest distance savings in the route is in suppliers B, F, $\mathrm{G}, \mathrm{J}, \mathrm{A}, \mathrm{L}, \mathrm{E}$, and $\mathrm{H}$ with the total delivery volume in this route is $36.66 \mathrm{~m}^{3}$, the delivery volume is suitable to the capacity of the truck. Next is counting the efficiency gained from regular transport by using wing box trucks: $\frac{36,66}{39,6} \times 100 \%=93 \%$

3. Determining truck visit order by Sweep method

From the calculation of truck visit order to each supplier, the total millage obtained equals to $163.26 \mathrm{~cm}$ :

Table 6 truck visit order by SweepMethod

\begin{tabular}{|l|l|l|l|l|l|l|l|l|l|}
\hline DC & H & L & F & A & B & G & J & DC & DISTANCE \\
\hline 11,50 & 0,81 & 23,22 & 23,31 & 23,26 & 23,18 & 23,36 & 23,08 & & 163,26 \\
\hline
\end{tabular}

B. The calculation of Distance, Time, and Costs

In this phase, the researchers calculate the total distance, lead time and total costs of milk run delivery method in trial period, starting from 
September 11, 2017 to September 24, 2017. Therefore, the effective work days in trial period are 10 days. Distance on the map shows $1.5 \mathrm{~cm}$ to every $2 \mathrm{~km}$ of actual distance. (Cost of renting a wing box truck/day is Rp. $1,500,000$ and cost $/ \mathrm{km}$ is Rp. 11,000).

Table 7 the result of calculation of actual distance, leadtime and total costs

\begin{tabular}{|c|c|c|c|c|c|}
\hline $\begin{array}{c}\text { Actual } \\
\text { Distance/ } \\
\text { day }(\mathrm{km})\end{array}$ & $\begin{array}{c}\text { Actual } \\
\text { Distance/10 } \\
\text { days }(\mathrm{km})\end{array}$ & $\begin{array}{c}\text { Loading } \\
\text { unloading } \\
\text { time } \\
\text { (minutes) }\end{array}$ & $\begin{array}{l}\text { Delivery } \\
\text { time } \\
\text { (minutes) }\end{array}$ & $\begin{array}{l}\text { Total } \\
\text { delivery } \\
\text { time }\end{array}$ & Total Costs \\
\hline 326,52 & 3265,20 & 36,66 & 326,52 & $\begin{array}{l}363,18 \\
\text { minutes } \\
6,05 \text { Hour }\end{array}$ & Rp50.917.200 \\
\hline
\end{tabular}

By assuming that the standard of loading/unloading time per $\mathrm{m}^{3}$ is 1 minute and standard vehicle speed is $60 \mathrm{~km} /$ hour.

Table 8. Comparison of milkrun method to direct shipment method.

\begin{tabular}{|c|c|c|c|c|c|c|}
\hline $\begin{array}{l}\text { Delivery } \\
\text { Method }\end{array}$ & $\begin{array}{c}\text { Actual } \\
\text { distance/10 } \\
\text { days }(\mathrm{km})\end{array}$ & $\begin{array}{l}\text { Difference } \\
\text { in distance }\end{array}$ & $\begin{array}{l}\text { Total } \\
\text { Delivery } \\
\text { time }\end{array}$ & $\begin{array}{l}\text { Difference } \\
\text { in time }\end{array}$ & $\begin{array}{l}\text { Total Cost } \\
\quad(\mathrm{Rp})\end{array}$ & $\begin{array}{c}\text { Difference } \\
\text { in Total } \\
\text { Cost }\end{array}$ \\
\hline Milkrun & 3265,2 & \multirow{2}{*}{$14 \%$} & $\begin{array}{c}363,18 \\
\text { minutes } \\
=6,05 \\
\text { Hour }\end{array}$ & \multirow{2}{*}{$13 \%$} & 50.917 .200 & \multirow{2}{*}{$43 \%$} \\
\hline $\begin{array}{c}\text { Direct } \\
\text { Shipment }\end{array}$ & 3811,6 & & $\begin{array}{c}417,82 \\
\text { minutes } \\
=6,96 \\
\text { Hour }\end{array}$ & & 89.927 .600 & \\
\hline
\end{tabular}

Based on the calculation above, it describes that the difference of the millage in direct shipment method and the milk run method is $14 \%$ and the reduction of vehicle leadtime is $13 \%$ while the costs is in $43 \%$

\section{Conclusion}

The result of this research shows that the application of Milk run method is more efficient and more effective compared to the direct shipment method. The milk run delivery method enables to minimize the delivery costs, improve distance efficiency, and minimize leadtime by finding the optimal route to get the best route combination by integrating several suppliers into one route within the capacity of trucks' total delivery volume. 
Suggestion, in order to attain more optimal result, further research concerning to the other delivery route needs to be conducted.

\section{References}

Bell, J. E., \& McMullen, P. R. (2004). Ant colony optimization techniques for the vehicle routing problem. Advanced Engineering Informatics, 18(1), 41-48. https://doi.org/10.1016/j.aei.2004.07.001

Endarwati, D. A., Mahmudy, W. F., \& Ratnawati, D. E. (2014). Pencarian Rute Optimum Dengan Evolution Strategies. DORO: Repository Jurnal Mahasiswa PTIIK Universitas Brawijaya, 4(10). Retrieved from http://filkom.ub.ac.id/doro/

Iqbal, K. (2013). Fundamental Engineering Optimization Methods.

Jamilson, M., Souza, F., \& Fluminense, U. F. (2011). A hybrid heuristic , based on Iterated Local Search and GENIUS , for the Vehicle Routing Problem with Simultaneous Pickup and Delivery Marcio Tadayuki Mine , Matheus de Souza Alves Silva, Luiz Satoru Ochi and Anand Subramanian, 10(2), 142-157.

Kilic, H. S., \& Durmusoglu, M. B. (2012). Classification and modeling for in-plant milk-run distribution systems, 1135-1146. https://doi.org/10.1007/s00170-011-3875-4

Kovács, A. (2011). Optimizing the storage assignment in a warehouse served by milkrun logistics. International Journal of Production Economics, 133(1), 312-318. https://doi.org/10.1016/j.ijpe.2009.10.028

Li, J. A., Wu, Y., Lai, K. K., \& Liu, K. (2008). Replenishment routing problems between a single supplier and multiple retailers with direct delivery. European Journal of Operational Research, 190(2), 412-420. https://doi.org/10.1016/j.ejor.2007.06.022

Nemoto, T., \& Rothengatter, W. (2012). Efficient Green Logistics in Urban Areas: Milk Run Logistics in the Automotive Industry. Sustainable Transport for Chinese Cities (Vol. 3). Emerald Group Publishing Limited. https://doi.org/10.1108/S2044-9941(2012)0000003017

Poot, a, Kant, G., \& Wagelmans, a P. M. (2002). A savings based method for real-life vehicle routing problems. Journal of the Operational Research Society, 53(1), 57-68. https://doi.org/10.1057/palgrave/jors/2601252

Pujawan\&Mahendrawathi, institute teknologi sepuluh N. (2010). Supply CHain Management (2nd ed.). Guna Widya.

Raden Didiet Rachmat Simarmata, J. H., \& Len Togas, N. (2015). Study on The Cause of Stock Out of Logistic Installation in Harapan Kita Hospital. Jurnal Manajemen Transportasi \& Logistik, 2(1), 79-92.

S, T. I. H. (2016). MULTIMODA DALAM MEWUJUDKAN VISI LOGISTIK INDONESIA 2025, 69-84.

Sadjadi, S. J., Jafari, M., \& Amini, T. (2009). A new mathematical modeling and a genetic algorithm search for milk run problem (an auto industry supply chain case study). International Journal of Advanced 
Manufacturing Technology, 44(1-2), 194-200. https://doi.org/10.1007/s00170-008-1648-5

Sari, L. M. (2015). PENGIRIMAN PRODUK ARNOTTS KE ALFAMART AREA JABODETABEK DAN BANTEN PT INTAN UTAMA LOGISTIK TAHUN 2015, (3), 11-20.

Supriyadi, S., Mawardi, K., \& Nalhadi, A. (2017). Minimasi Biaya Dalam Penentuan Rute Distribusi Produk Minuman Menggunakan Metode Savings Matrix. Seminar Nasional Institut Supply Chain Dan Logistik Indonesia (ISLI), (September), 1-7. https://doi.org/DOI 10.17605/OSF.IO/2D9GP

Toth, P., \& Vigo, D. (2002). Models, relaxations and exact approaches for the capacitated vehicle routing problem. Discrete Applied Mathematics, 123(1-3), 487-512. https://doi.org/10.1016/S0166-218X(01)00351-1

Witlox, F. (2007). Logistics systems for sustainable cities. Cities, 24(6), 462463. https://doi.org/10.1016/j.cities.2007.07.003. 